\title{
Ketidakadilan Gender Pada Perempuan Karo di Desa Purwobinangun (Kajian Wacana Kritis).
}

\author{
Erlinda Nofasari ${ }^{1}$, Sri Ulina Beru Ginting ${ }^{2}$ \\ Dosen STKIP BUDIDAYA BINJAI \\ linaginting31@gmail.com²
}

\begin{abstract}
ABSTRAK
Ketidakadilan gender termanifestasi dalam berbagai bentuk yaitu subordinasi, marginalisasi dan diskriminasi, suatu jebakan dimana menempatkan perempuan hanyalah sebagai istri yang baik dan ibu yang baik dikeluarga dan dimasyarakat . Subordinasi merupakan keterpinggiran perempuan berperan didalam adat,dan mengiakan hasil dali pembicaraan tanpa berperan dalam mengambil sebuuah keputusan. perempuan hanya sebagai pendengar pada saat adat berjalan. Perempuan Karo di Desa Purwobinangun adalah perempuan yang pekerja keras, apapun ia lakukan demi keluarga dan anak-anaknya. Perempuan Karo mempunyai tanggung jawab yang besar didalam keluarga,baik di keluarga mertuanya maupun dikeluarga orang tuanya.keterpinggiran perempuan tergamabr jelas apabila ia tidak mampu memberikan keturunan anak laki-laki, karena anak laki-laki merupakan pembawa status social. Adapun tujuan dari penelitian ini adalah untuk mengetahui bagaimana ketidakadilan gender pada perempuan Karo. Metode dalam penelitian ini adalah kulitatif deskriftif dan mengunakan pendekatan fenomenologi. Teknik pengumpulan data dalam penelitian ini mencakup: Observasi, wawancara, Dokumentasi. Ideologi familialisme pada perempuan Karo tergambar bagimana perempuan pekerja keras yang memperjuangkan agar orang-orang yang ia kasihi mendapat yang terbaik di dalam kehidupannya, tanpa memperhitungkan pengorbanan baik moril maupun materil.Gambaran potret ketidakadilan gender pada perempuan Karo, seorang ibu yang baik itu pasti memperjuangan segala bentuk apapun demi memenuhi kebutuhan hidup anak-anaknya agar dapat bersekolah kejenjang yang lebih baik serta juga harus mampu merias diri untuk memberi pelayanan yang terbaik bagi suami.Pengorbanan inilah yang akan mengangkat status sosial keluaraga ketika anak anak yang mereka perjuangkan berhasil.
\end{abstract}

Kata Kunci : Ideologi Familialisme, Perempuan Karo, Perempuan Jawa, Wacana Kritis.

\section{A. PENDAHULUAN}

Identitas gender merupakan perasaan subyektif tentang keberadaan seseorang sebagai laki-laki atau perempuan dan merupakan bagian penting dari seseorang. Pada sukuKaro terkadang muncul ketidak adilan gender dengan laki laki, di mana upah laki laki bekerja lebih besar dari pada upah perempuan bekerja di ladang petani. Dalam kehidupan perempuan turut serta dalam menopang kehidupan keluarga, peran perempuan Karo sudah jauh berbanding terbalik dengan ideologi gender, di Desa Purwobinangun mayoritas mata pencaharian penduduknya adalah petani, di mana mereka harus berangkat keladang jam setengah delapan pagi dan akan tiba kembali di rumah jam dua belas siang, aktifitas mereka di ladang membersihkan rumput yang ada di antara tanaman, memupuk tanaman dan memanen hasil pertanian.

Ketidak adilan gender menurut siti sakdiah merupakan suatu jebakan dimana menempatkan perempuan hanyalah sebagai istri yang baik dan ibu yang baik.Perempuan harus bisa berhias diri untuk bisa memberi pelayanan yang terbaik bagi suami. Pada suku Karo dan suku Jawa di Desa Purwobinangun, ketidakadilan gender membatasi ruang gerak pada permpuan Karo, bagaimana subordinasi, marginalisasi dan diskriminasi mengikat mengikat ruang gerak mereka. Keterbatasan perempuan 
dalam subordinasi. Perempuan Karo mempunyai tanggung jawab yang besar didalam keluarga,baik di keluarga mertuanya maupun dikeluarga orang tuanya.

Dapat kita lihat bagaimana pada saat adat berlangsung kaum perempuan tidak boleh ikut campur dalam musyawarah, mereka hanya sebagai pendengar dan mengiakan keputusan yang diambil. Menurutt Tarigan di keluarga mertua perempuan Karo kedudukannya sebagai Kalimbubu, di keluarga orang tuanya perempuan Karo posisinya sebagai sebagai anak beru . Dari hasil pengamatan peneliti, perempuan di desa Purwobinangun yang sangat berperan menopang kehidupan perekonomian didalam keluarga, pada saat jam kerja mereka melaksanakan tugasnya di ladang sementara kaum laki laki menghabiskan waktunya duduk duduk santai di kedai kopi sambil bermain catur, tanpa ada rasa prihatin melihat istri mereka yang banting tulang di bawah terik matahari mengerjakan lahan pertanian mereka.. Kedudukan anak perempuan juga sangat disikriminasi karena anak perempuan pada perempuan Karo tidak boleh keluar dari kampung apabila mereka belum menikah. Untuk melanjutkan pendidikan keluar kotapun orang tua mereka tidak mengijinkan, karena kekawatiran orang tua terkadang sangat berlebihan. Tetapi untuk anak laki laki lebih mereka prioritaskan apalagi disaat panen Kaum laki-laki turut serta ke ladang apabila tanaman pertanian mereka ada yang panen, pada umumnya tanaman yang ditanam adalah tanaman palawija. Dari pemaparan diatas terbentuklah profil gender Nrimo, pasrah, tidak banyak tuntutan, dan selalu berusaha menutup diri, agar semuanya berjalan aman, tidak menimbulkan konflik, baik di lingkungan keluarga maupun masyarakat.

Berdasarkan latar belakang di atas dapat dilihat secara kasat mata ketidakadilan gender terdapat pada kaum perempuan Karo di desa
Purwobinagun, secara umum dapat dikatakan kajian perempuan atau analisis gender mencoba mengangkat kepermukaan menurut Fakih ketidakadilan dan kesetaraan gender secara struktural dan kultural dapat diwujudkan, analisis gender bukan sekedar kajian tentang perempuan, tetapi juga kajian terhadap isu perempuan, perspektif perempuan, kepentingan perempuan, perbaikan kedudukan dan peran perempuan, sejarah perempuan, sosok perempuan.. Dalam penelitian ini akan membahas " ketidakadilan gender pada perempuan Batak Karo di Desa Purwobinangun Kajian wacana kritis"

\section{B. METODE}

Penelitian ini berdesain bermetode penelitian kualitatif , yang mengkaji Ideologi gender dalam ketidakadilan gender pada perempuan Batak Karo dan di Desa Purwobinangun Kecamatan Sei.Bingai kabupaten Langkat. Menurut Moleong (2014:4) bahwa metode kualitatif sebagai prosedur penelitian menghasilkan data deskriptif berupa kata-kata tertulis atau lisan dari orang-orang dan prilaku yang dapat diamati.

Metode penelitian yang digunakan peneliti ini adalah metode kualitatif deskriptif analisis. ratna (2008:53) menyatakan bahwa metode deskriptif analisis dilakukan dengan cara mendeskripsikan fakta-fakta yang kemudian disusul dengan Analisis. Metode penelitian ini mengkaji antara lain menentukan lokasi pelaksanaan penelitian, teknik pengumpulandata,analisis data, menentukan sumber data, jadwal penelitian, sertamerincikan luaran penelitian pertahun dan indikator capaian. Metodologi adalah metode untuk memperoleh pemahaman objek yang akan diteliti untuk memenuhi tujuan penelitian Hoed (2008:6) dalam penelitian ini, peneliti fokus dalam tiga tahapan kegiatan terhadap objek 
penelitian yang mencakup (1) Pengumpulan data (2) Pengolahan data (3) Penganalisisan data untuk memperoleh hasil dari Idiologi familialisme yang terkandung pada perempuan Karo dan Perempuan Jawa.

\section{Lokasi dan Waktu Penelitian}

Penelitian ini dilaksanakan di Dusun V Sumber Muliyo dan Dusun VI Serbajadi Desa Purwobinangun Kecamatan.Sei. Bingai Kabupaten Langkat.

\section{Subjek dan Objek Penelitian}

Subjek Penelitia. Subjek penelitian merupakan keseluruhan yang dilengkapi dengan ciri-ciri permasalahan yang baru diteliti, sehingga suatu penelitian harus jelas Subjek penelitiannya. Sugiyono (2016: 80) mengatakan “ Subjek penelitian adalah wilayah generelisasi yang ditetapkan oleh peneliti untuk dipelajari dan ditarik kesimpulannya". Berdasarkan pendapat diatas maka subjek yang diambil dalam penelitian ini adalah Masyarakat suku Karo yang berdomisili tetap di Desa PurwoBinangun Kecamatan Sei-Bingei, Kabupaten Langkat

Objek Penelitian. Arikunto (2006:131) mengatakan "Objek Penelitian adalah sebagian atau wakil yang akan di observasi oleh peneliti”.Sugiyona (2016:81) mengatakan "Objek penelitian adalah bagian dari jumlah karakteristik yang dimiliki oleh narasumber tersebut". Dalam penelitian yang direncanakan ini, informan yang akan dijadikan Objek adalah perempuan yang bersuku Karo yang berdomisili tetap di Desa Purwobinagun Kec. Sei.Bingai Kabupaten Langkat.

\section{Metode dan teknik Pengumpulan Data}

Metode dan teknik pengumpulan data merujuk pada Suharsimi Arikunto

2006:22 ) yang menyatakan bahwa penelitian kualitatif menuntut peneliti terlibat langsung dalam interaksi sosial walupun terkadang memakan waktu yang lama. Dengan demikian, peneliti ikut terlibat langsung dalam aktifitas yang akan diteliti dalam pengumpulan data. Metode dan teknik pengumpulan data dalam penelitian ini mencakup : (1) Observasi (2) wawancara (3) Dokumentasi . Ketiga metode dalam penelitian ini dapat dipaparkan sebagai berikut.

Metode Observasi. Bungin (2008:115) menyatakan bahwa metode observasi adalah metode penggumpulan data digunakan untuk menghimpun data penelitian melalui pengamatan dan pengindraan peneliti. Dalam penelitian ini metode pengumpulan data simbol verba dan nonverba pada idiologi gender pada perempuan Batak Karo dan Jawa dilakukan melalui pengamatan dan pengindraan secara langsung di desa PurwoBinangun Kecamatan Sei.Bingai Kabupaten Langkat.

Metode Wawancar.Metode wawancara dalam penelitian ini merujuk pendapat Hoed (2008:18) yang menyatakan bahwa wawancara adalah proses pengumpulan data yang diperoleh dari informen. Dalam penelitian ini terlebih dahulu peneliti memilih orang sebagai narasumber terkait dengan Idiologi gender pada wacana kritis. Pada metode wawancara ini peneliti melakukan wawancara secara bebas dengan melakukan tanya jawab secara bebas kepada informan, dan wawancara mendalam merujuk kepada rumusan masalah kepada informan kunci atau narasumber

Metode Dokumentasi. Metode dokumentasi dalam penelitian ini merujuk pada pendapat Arikunto (2006: 231) yang menyatakan metode dokumentasi ,yaitu mencari data mengenai hal-hal atau variabel yang berupa catatan, transkrip, buku, surat kabar, majalah, prasasti, notulen rapat, lengger, agenda dan sebagainya 
Metode dan Teknik Analisis Data Metode dan teknik analisis data dalam penelitian ini mencakup dua bagaian, yang terdiri daria: (1) Metode Analisis Data dan (2) teknik Analisis data,

Metode Analisis Data. Metode analisis data dalam penelitian ini merujuk Kridalaksana (2007:11) menyatakan bahwa linguistik mendekati bahasa dengan metode induktif dan metode dekriptif - kualitati. Analisis data dilakukan dengan teknik observasi, wawancara dan dokumen serta study kepustakaan. Nasution (dalam sugiyono, 2009: 226) mengatakan" Observasi sebagai teknik pengumpulan data mempunyai cara spesifik bila dibanding dengan teknik lain". Sugiyono dalam (sutrisno 1986: 145) mengatakan “observasi merupakan suatu proses yang kompleks, suatu proses yang tersusun dari berbagai proses biologis dan psikologis". Jadi dalam pengumpulan data yang bersifat kualitatif adalah observasi tentang proses-proses pengamatan dan ingatan. Proses pengumpulan data dimulai dengan pengelompokan data-data yang terkumpul melalui wawancara dan kajian pustaka maupun catatan yang dianggap dapat menunjang dalam penelitian ini untuk diklasifikasi dan dianalisis untuk kepentinagn penelitian.

Teknik Pengumpulan Data . Teknik pengumpulan data yang digunakan dalam penelitian ini adalah dengan pengamatan fenomenologi serta pengumpulan data dengan menggunakan angket pertanyaan dan wawancara. Bentuk angket pertanyaan adalah pemaparan luas tentang jawaban dari pertanyaan yang diberikan oleh peneliti.

Teknik Analisis Data. Moleong menyatakan " Analisis telah dimulai sejak merumuskan dan menjelaskan masalah. Sebelum terjun kelapangan dan berlangsung terus sampai penulisan hasil penelitian" Pada tahapan teknik analisis data, peneliti akan menggunakan teknik analisis komponensial (componential analysis) dengan dokumen. Teknik analisis ini cara tepat untuk penelitian ini dikarenakan cocok dengan pengertian dasarnya dan cara kerjanya dilakukan melalui observasi. Adapun teknik analisis data yang akan digunakan tahap pertama 1). Data dicatat dari informan yang menjadi narasumber peneliti. 2). Data yang bersumber dari rekaman ditranskrip aslinya dan diterjemahkan ke dalam bahasa Indonesia. 3). Data yang telah diperoleh dianalisis sesuai teori Idiologi Gender.

\section{Metode dan teknik Pengumpulan}

Data. Metode dan teknik pengumpulan data merujuk pada Suharsimi Arikunto ( 2006:22 ) yang menyatakan bahwa penelitian kualitatif menuntut peneliti terlibat langsung dalam interaksi sosial walupun terkadang memakan waktu yang lama. Dengan demikian, peneliti ikut terlibat langsung dalam aktifitas yang akan diteliti dalam pengumpulan data. Metode dan teknik pengumpulan data dalam penelitian ini mencakup : (1) Observasi (2) wawancara (3) Dokumentasi . Ketiga metode dalam penelitian ini dapat dipaparkan sebagai berikut:

Metode Observasi. Bungin (2008:115) menyatakan bahwa metode observasi adalah metode penggumpulan data digunakan untuk menghimpun data penelitian melalui pengamatan dan pengindraan peneliti. Dalam penelitian ini metode pengumpulan data simbol verba dan nonverba pada ideology familialisme

Metode Wawancara Metode wawancara dalam penelitian ini merujuk pendapat Hoed (2008:18) yang menyatakan bahwa 
wawancara adalah proses pengumpulan data yang diperoleh dari informen. Dalam penelitian ini terlebih dahulu peneliti memilih orang sebagai narasumber terkait dengan Idiologi gender pada wacana kritis.

Metode Dokumentasi. Metode dokumentasi dalam penelitian ini merujuk pada pendapat Arikunto (2006: 231) yang menyatakan metode dokumentasi ,yaitu mencari data mengenai hal-hal atau variabel yang berupa catatan, transkrip, buku, surat kabar, majalah, prasasti, notulen rapat, lengger, agenda dan sebagainya.

\section{Metode dan Teknik Analisis}

Data. Metode dan teknik analisis data dalam penelitian ini mencakup dua bagaian, yang terdiri daria: (1) Metode Analisis Data dan (2) teknik Analisis data, kedua hal diatas dijelaskan dibawah ini.

Metode Analisis Data. Metode analisis data dalam penelitian ini merujuk Kridalaksana (2007:11) menyatakan bahwa linguistik mendekati bahasa dengan metode induktif dan metode dekriptif - kualitati. Analisis data dilakukan dengan teknik observasi, wawancara dan dokumen serta study kepustakaan. Nasution (dalam sugiyono, 2009: 226) Jadi dalam pengumpulan data yang bersifat kualitatif adalah observasi tentang proses-proses pengamatan dan ingatan.

Teknik Pengumpulan Data .Teknik pengumpulan data yang digunakan dalam penelitian ini adalah dengan pengamatan fenomenologi serta pengumpulan data dengan menggunakan angket pertanyaan dan wawancara. Bentuk angket pertanyaan adalah pemaparan luas tentang jawaban dari pertanyaan yang diberikan oleh peneliti.

Teknik Analisis Data. Burhan Bunggin menyatakan " Analisis telah dimulai sejak merumuskan dan menjelaskan masalah. Sebelum terjun kelapangan dan berlangsung terus sampai penulisan hasil penelitian" Adapun teknik analisis data yang akan digunakan tahap pertama 1). Data dicatat dari informan yang menjadi narasumber peneliti. 2). Data yang bersumber dari rekaman ditranskrip aslinya dan diterjemahkan ke dalam bahasa Indonesia. 3). Data yang telah diperoleh dianalisis sesuai teori ketidakadilan gender.

\section{HASIL DAN PEMBAHASAN. HASIL}

Penelitian yang dilakukan oleh peneliti di Desa Puwobinangun, dimana peneliti menemukan yaitu

\section{Ketidakadilan Gender}

Ketidak adilan gender terjadi karena adanya perbedaan gender, ketidakadilan gender pada perempuan Batak Karo dan perempuan Jawa di desa purwobinangun termanifestasi dalam berbagai bentuk yaitu subordinasi, marginalisasi dan diskriminasi. Ginting Sri Ulina (2018:533) juga menyatakan pembahwa status sosial pada keluarga orang Karo adalah anak laki-laki, itulah yang menjadi kebanggaan orang tua. Ammalia dan Agustya menyatakan seorang perempuan itu harus berpendidikan tinggi dan bekerja di ruang public, dari pernyataan Ammailia 
bertolak belakang dengan siatuasi yang didapat oleh peneliti dilapangan, adapun bentuk ketidakadilan gender yang peneliti temukan pada saat pengumpulan data pada responden yang di wawancarai dapat terlihat pada pemaparan berikut di bawah ini.

a. Subordinasi

Subordinasi terhadap perempuan adalah keterpinggiran perempuan di tengah masyarakat. Subordinasi yang tergambar dalam penelitian yang di laksanakan peneliti di Dusun VI Serbajadi desa Purwobinangun dimana masyarakatnya mayorias bersuku Karo adalah sebagai berikut:

Saya sudah 15 tahun menikah, dan tidak punya anak anak laki-laki,anak saya 3 perempuan semua. Tapi syukurlah ibu mertua dan suami saya tidak banyak tuntutannya dan tidak terlalu menyinggun, jadi saya tidak terlalu cemas.Karena kami orang Karo banyak kali aturan dalam Adat, yang penting anakku sudah ada walau perempuan.Meskipun

didalam adat Karo perempuan itu tidak banyak perannya setidaknya tempat akhir tuaku sudah ada.Dalam adat Karo anak perempuan itu tidak bisa jadi anak beru singerana, anak beru singerana itu harus anak laki-laki.jadi peran anak perempuan didalam menjalankan adat kecil sekali.

Tuturan ibu Deliana diatas menggambarkan terpinggirnya perempuan didalam adat, pada posisi anak beru si ngerana (anak beru yang berbicara pada posisi adat). Perempuan dianggap tidak layak berbicara didalam adat di posisi anak beru si ngerana.Dalam tuturan diatas bahwasanya untuk kaum perempuan pada suku Karo hanya sebagai pendengar dan mengiakan hasil percakapan yang ada. Selanjutnya penuturan ibu Deliana menggambarkan keterpinggiran perempuan apa bila tidak memiliki anak, khususnya anak laki-laki. tapi bersyukurnya ibu deliana suaminya tidak terlalu mempermasalahkan ketika mereka tidak memiliki anak laki-laki.

Karena pada suku Karo, anak laki-laki itu merupakan sebagai pembawa status sosial keluarga di dalam masyarakat. Apabila anak laki-laki pada suku Karo sukses dan memiliki keturunan anak lakilaki dan anak perempuan itu merupakan suatu kebanggaan bagi keluarga seperti ungkapan yang di sampaikan pada saat pesta perkawinan sebagai pesan kepada pengantin yaitu merih manuk ni asuh, mbuah page si ni suan jumpa bulan ras mata wari yang maknanya tercapai capai segala apa yg di usahakan dan terpenuhi segala keinginan mempunyai keturunan anak laki-laki dan anak perempuan. Tapi ketika ia tidak 
mempunyai keturunan anak lakilaki dianggap istrinya tidak membawa keberuntungan.

Tapi di kehidupan jaman sekarang sudah adanya kesadaran orang tua tidak lagi terlalu menuntut cucu laki laki terhadap anak laki-lakinya yang sudah menikah. Terlihat pada penuturan ibu Deliana diatas,

"Saya sudah 15 tahun menikah, dan tidak punya anak anak laki-laki, anak saya 3 perempuan semua.Tapi syukurlah ibu mertua dan suami saya tidak banyak tuntutannya dan tidak terlalu menyinggung, jadi saya tidak terlalu cemas.Dulu sempat juga saya khawatir karena teman saya, tidak mempunyai anak laki-laki diam diam suaminya menikah lagi tanpa sepengetahuan istrinnya ".

Pemikiran orang tua yang lahir di tahun 40-an dan 50-an pasti jika anak laki-lakinya tidak memiliki keturunan anak laki-laki, pasti ia sudah menikahkan lagi anak laki-lakinya. Karena istrinya dianggap tidak dapat meneruskan marga, jadi tergambar pendiskriminasian kaum perempuan pada suku Karo dimana diskriminasi itu adalah di luar dari kemauan kaum perempuan, yang ia harus terima dengan pahit ketika keadaan tidak berpihak kepadanya seperti yang dituturkan ibu Deliana tentang temannya yang tidak mempunyai anak laki-laki suaminya menikah lagi secara diam diam. Marginalisasi

Marginalisasi adalah bentuk ketidakadilan berupa pembatasan terhadap gerak kaum perempuan. Marginalisasi terdapat perempuan yang muncul pada perempuan Batak Karo dan perempuan Jawa sewaktu peneliti melakukan penelitian di dusun V Sumber Mulio dan dusun VI Serbajadi terlihat pada penuturan ibu Deliana berikut ini:

Suami saya melarang anak perempuannya untuk merantau bekerja ke luar negeri atau ke daerah lain, suami saya mau kami kumpul semua disini. waktu mau kuliah anak perempuan saya tidak di kasi untuk mengambil di luar kota medan, jika luluspun kamu nanti kamu tidak bapak ijinkan berangkat, di Medan bolehlah kan dekat bisa pulang berulang jika kuliah.

Jelas terlihat dalam tuturan ibu deliana bahwa ke inginan anaknya untuk melanjutkan kuliah di luar propinsi tidak di ijinkan suaminya, dalam gambaran ini dimana karena ada rasa kekawatiran suaminya untuk berjauhan dengan anak perempuannya, jadi terdapat pembatasan gerak terhadap kaum perempuan tidak di ijinkan melanjutkan kuliah luar dari kota 
medan apalagi menjadi TKW ke luar negeri.

Bentuk ketidakadilan gender berupa marginalisasi dimana pembatasan gerak bagi kaum perempuan Karo di bidang adat, dimana seperti penuturan responden $\mathrm{S} . \mathrm{Br}$ Ginting ketika diwawancarai oleh peneliti terlihat penuturan beliau sebagai berikut:

Pada suku Karo, peran perempuan sangat minim sekali dimana semuanya laki-laki yang menjalankannya. Untuk anak beru si ngerana didalam adat tidak ada perempuan sebagi anak beru singerana melainkan lakilaki lah yang paling berperan, itulah aturan dalam adat Karo. Suami saya selalu menjadi anak beru si ngerana didalam pesta adat perkawinan maupun pesta kematian dalam adat.hingga sangkinseringnya pesta saya kemalahan untuk mengasi pertama, karena pendapatan kami dari ladang.

Dalam kutipan diatas tergambar ketidak adilan gender dalam bentuk marginalisasai dimana pembatasan gerak kaum perempuan dalam adat Karo, karena sebagi anak beru singerana perempuan itu dianggap tidak layak atau belum layak hingga anak lakilakilah yang paling mengambil peran.

\section{PEMBAHASAN}

Dari hasil pengumpulan data dan penganalisisan data terlihat jelas bahwa perempuan Batak Karo di Desa Purwobinagun merupakan perempuan yang mandiri dimana mereka tidak tergantung pada suami sebagai sumber ekonomi keuangan di keluarga. Kreatif dan inovatif memiliki semanagat dan jiwa jiwa perubahan dalam menyikapi berbagai fenomena didalam keluarga.

Perempuan Batak Karo memiliki jiwa kepemimpinan, mereka mulai mampu melawan dominasi lakilaki,sehingga mereka mampu membuktikan kepada semua orang bahwa perempuan memiliki kemampuan yang sama dengan laki-laki serta mampu membantah asumsi ketidakadilan gender yang sangat berkembang. Pada suku Karo anak laki-laki yang paling dianggap bertanggung jawab terhadap kedua orang tuanya kelak di hari tua, anak laki-laki yang akan mengurus ayah ibunya disaat sudah tua. sedangkan anak perempuan dianggap hanya sebagai pendamping di dalam keluarga. Tapi pada kenyataannya sekarang di desa purwobinangun justru di anak perempuannlah orang tua mereka tinggal dan anak perempuanlah yang mengurus kedua orang tuanya .

Dalam kenyataan sebenarnya anak laki-laki hanya sebagian kecil yang mengurus orang tuanya, justru anak perempuanlah yang mengurus orang tuanya, dilihat dari pengamatan yang dilakukan oleh peneliti terhadap beberapa sumber responden. Gender yang muncul karena adanya pengaruh sosial dan kultural menyebabkan ketimpanganketimpangan dalam masyarakat. Sistem patriarki yang dominan erat dalam 
kehidupan masyarakat menyebabkan ketidakadilan pada salah satu jenis kelamin yaitu perempuan. Ginting.Sri Ulina Dkk menyatakan (2018;759) menyatakan perempuan dianggap sebagai makhluk kelas dua. makhluk lemah,tidak berdaya, emosional, dan pekerja rumahan. Dalam penuturan responden ketika di wawancarai dan dari hasil analisis angket pertanyaan yang di bagi peneliti pada sumber objek penelitian yaitu pada permpuan Batak Karo dan perempuan Jawa di Desa Puwobinangun, dimana hasil penelitian yang dilakukan peneliti, peneliti menemukan bagaimana perempuan Karo dan perempuan Jawa cenderung ber empati terhadap ideology familialisme di Desa Purwobinagun Kecamatan Sei.Bingai. Dalam penelitian ini kenapa perempuan harus berpendidikan? karena kehidupan kedepannya ia setara dengan pria, bukan menghilangkan sosok kodrat sebagai kaum perempuan, karena kaum laki-laki sering berpikir bahwa kaum wanita hanya mampu menghabiskan uang mereka. Jika perempuan memiliki penghasilan dalam pekerjaan tidak akan ada kaum laki -laki yang merendahkan derajat kaum perempun.

Didalam kehidupan sehari hari sudah ada pembagian tugas dan tangung jawab orang tua terhadap anak. Dulunya orang tua sebagai bapak hanya berperan sebagai pencari nafkah untuk keluarga , tanpa harus memikirkan membantu istri dalam mengurus, merawat dan membesarkan anaka anak.

\section{SIMPULAN}

Setelah peneliti melakukan pengumpulan data, data diolah menjadi data yang akurat. Dari hasil penelitian maka peneliti menyimpulkan : perempuan Karo adalah perempuan yang pekerja keras, apapun ia lakukan demi keluarga dan anak-anaknya. Perempuan Karo mempunyai tanggung jawab yang besar didalam keluarga, baik di keluarga mertuanya maupun dikeluarga orang tuanya. Karena di keluarga mertua perempuan Karo kedudukannya sebagai Kalimbubu, di keluarga orang tuanya perempuan Karo posisinya sebagai sebagai anak beru.

Ketidakadilan gender pada perempuan Batak Karo yang ditemukan peneliti pada saat melakukan penelitian di Desa Purwobinagun yaitu. potret budaya Familialisme dimana seorang ibu yang baik itu pasti memperjuangan segala bentuk apapun demi memenuhi kebutuhan hidup anak-anaknya agar dapat bersekolah, meskipun terlihat dengan jelas ketidakadilan gender pada perempuan Karo namaun karena adanya rasa kepedulian seorang ibu terhadap dibidang pendidikan dan pekerjaan bagi anak anak perempuan mereka, meskipun demikian perlawanan ini tidak bertentangan dengan aturan adat. Dimana dulunya pada masa mereka, anak perempuan tidak di prioritaskan dalam sekolah keperguruan tinggi dan dalam mengambil pekerjaan oleh orang tua mereka, orang tua lebih mengutamakan anak laki-laki dibanding anak perempuan.

\section{DAFTAR PUSTAKA}

Anna. Rindhian Tika. Perempuan Pebisnis Dalam Budaya Jawa Di Semarang. Jurnal 
Ammalia,Agustya2013..Wacana Peran Perempuan Dalam Kolom Story Rubrik For Her Surat Kabar Jawa Pos. Jurnal sastra Indonesia .JSI 2 (1)

Anugriaty.2015.Bias Gender Sebagai Prediktor Kekerasan Dalam Rumah Tangga. Jurnal Psikologi.UGM.Volume 35.No.1,120.

Artawan.Gde.2018. Menembus Patriarki: Refleksi Perjuangan Perempuan Bali dalam Novel Indonesia.Depok:Rajawali Perss

Bungin, Burhan.2009.Metode Penelitian Kualitatif. Jakarta:Preda

Dwi.Astuti.2016.Media Dan Gender ( StudiDeskriptif Represtatif Stereotef Perempuan Dalam Iklan di Tv Swasta) Jurnal Poetika.Vol 09/N0.12.25-32.

Fakih, Mansour.2013. Analisis Gender dan Transformasi Sosial. Yogyakarta: Pustaka Pelajar.

Farah Dina, Representasi ideologi patriarki Dalam Novel Tanah Tabu Kajian Feminisme Radikal. Jurnal sastra Indonesia .JSI 2 (1) 2013.

Ginting.Sri Ulina .Semiotik Makna Pada Wacana Ngemah Belo Selambar Adat Karo Langkat (Kajian Semiotika Sosial) Jurnal Pena Indonesia.Unesa Vol.3,No.2 (2017) Hal 130-146.

Ginting.Sri Ulina.Dkk.Ideologi Gender: Refleksi Pejuangan Perempuan Karo dan Perempuan Jawa Dalam Dominasi Laki-Laki. Prosiding Seminar Internasional Riksa Bahasa XII. Hal.759-768
Ginting.Sri Ulina.Ideologi Gender Pada Perempuan Karo dan Perempuan Jawa di Desa Purwobinangun (Kajian Wacana Kritis).Jurnal SENAR Vol.1, No.1 Hal 553-536.

Kusmana.2014. Jurnal Refleksi. Menimbang Kodrat Perempuan anatar Nilai Budaya dan kategori Analisis. Volum 13.N0 6 april. 780-802.

Moleong.Lexy.J.2014.Metode Penelitian Kualitatif(EdisiRevisi).Bandung:Re maja Rosdakarya

Ni.made Diska.2014. Kesertaraan Dan Keadilan gender Dalam pandangan perempuan Bali : Studi Fenomenologis Terhadap Penulis perempuan Bali. Jurnal Psikologi Undip.Vol.13No.2. 149-162

Prinst, Darwan. prinst, Darwin.1985. Sejarah dan Kebudayaan Karo.Bandung:Yrama Widya.

Rhesa Zuhriya.2015. Pola Komunikasi Perempuan Dalam Mengkrontksi Identitas Gender Pada Gerakan PKK.Jurnal Of Rural and Development. VolumeVI No.1 Febuari.Hal 85-100

Sitepu. A. G, Dkk ,2002. Pilar Budaya Karo. KabanJahe: Abdi Karya

Siti Rokhimah.2014. Patriarkhisme Dan Ketidakadilan Gender. Jurnal Muwazah.Volume 6. Nomor 1. Hal 132-145.

Sugiyono.2016. Metode Penelitian Kuantitatif, Kualitattif dan $R \quad \& \quad D$. Bandung: Alfabeta. 
Tarigan, Sarjani. 2009. Lentera Kehidupan

Orang Karo Dalam Berbudaya. Medan:

SI BNB-BABKI, BABKI

Yoce, Aliah Darma .2014 Analisis Wacana

Kritis.Bandung: Yrama Widya 